\title{
Effects of diluents, dilution ratios and cryoprotectants for the cryopreservation of Thai Sharpunti (Barbodes gonionotus) spermatozoa
}

\author{
Uddowla $\mathrm{MH}^{1}$, Salma $\mathrm{U}^{2}$, Rahman $\mathrm{MM}^{1}$, Hossain $\mathrm{MS}^{3}$ and Mollah MFA ${ }^{1}$ \\ ${ }^{1}$ Dept of Fisheries Biology and Genetics, ${ }^{2}$ Dept of Aquaculture, Faculty of Fisheries, Bangladesh Agricultural \\ University, Mymensingh, Bangladesh, ${ }^{3}$ Department of Aquaculture, Faculty of Fisheries, Sylhet Agricultural \\ University, Sylhet, Bangladesh.
}

[Received: 19 May, Accepted: 16 June, 2011]

\begin{abstract}
Attempts were made to develop a protocol for the long term cryogenic freezing of Thai sharpunti (Barbodes goininotus) spermatozoa to maintain the gene pool as well as biodiversity. For these purpose, experiments were carried out with three specific objectives i.e., to find out the suitable diluents, dilution ratios (milt: cryodiluents) and suitable cryoprotectants. Effects of as many as 12 diluents and the three cryoprotectants were tested initially for the post thawed spermatozoa motility. Among the 12 diluents which gave more than $50 \%>$ motility in equilibrated periods (10-15 mins. of mixing with cryodiluents) were subsequently used for cryopreservation. Urea-egg-yolk as diluents was the most effective among the 12 diluents followed by egg-yolk citrate and Korokura solution. Urea-egg-yolk showed $52.91 \%$ spermatozoa motility on its $1^{\text {st }}$ day and $46.87 \%$ on $30^{\text {th }}$ day whereas egg-yolk citrate solution showed $46.25 \%$ and $38.53 \%$ motility on $1^{\text {st }}$ and $30^{\text {th }}$ day respectively. Four dilution ratios 1:3, 1:4, 1:5 and 1:6 were used out of which 1:5 seemed to be most suitable on both of Urea-eggyolk and egg-yolk citrate. To select the best fraction (\%) of cryoprotectants to the diluents trials were given with DMSO, glycerol, ethanol at $10 \%$ and a combination of 5\% DMSO and 5\% glycerol. Ten percent DMSO and combination of 5\% DMSO + 5\% glycerol was proven best. Proper application of this technology in field could be effective tools for protecting the endangered species in Bangladesh
\end{abstract}

Key words: Milt, diluents, Spermatozoa, Cryoprotectants, cryopreservation.

\section{INTRODUCTION}

Cryopreservation of fish deals with the cryobiology that relates the long-term preservation and storage of biological materials at a very low temperature, usually at $-196^{\circ} \mathrm{C}$. At this temperature the cellular viability can be stored in a genetically stable form. Cryopreserved sperm can preserve the fertility potential of fish for many years. The conservation of cryopreserved gametes of endangered species is an attempt to maintain genetic resources in an identifiable and potentially usable form. Sperm that is properly cryopreserved and stored can easily be used to produce animals that contain conserved genetic information as well as to preserve gene pool of important and endangered species in many countries with potential to improve quality seed production. The inbreeding co-efficient could also be minimized by adopting proper selection programme in artificial breeding. The reduction in heterozygosity due to the use of limited number of breeders could be possible to minimize using cryopreserved milt of selected strains. Sperm collection is one of the main problems in cyprinid aquaculture and in many cases; it must be assisted by hormonal injection ${ }^{[1]}$. Besides this, there are some species which are asynchronous spawners and create barrier for the artificial insemination in time. Considering the importance of cryogenic freezing, attempted has been made for the long-term cryogenic freezing of thai sharpunti ( $B$. gonionotus) spermatozoa.

Thai sharpunti (B. gonionotus) is an indigenous food fish of Thailand; locally called "Rajputi" has already been introduced in many south East Asian countries for its palatability and marketability and for its ease of breeding and high potential yield. In 1977, the fish was first introduced into Bangladesh from Thailand [2]. A $100 \mathrm{~g}$ Thai sharpunti contains $19 \mathrm{~g}$ protein, $2.0 \mathrm{~g}$ fat, and $150 \mathrm{mg}$ calcium and $990 \mathrm{mg}$ phosphorus. It may attain a weight of $150-200 \mathrm{~g}$ within six months and ready for harvesting. This species attains a sexual maturity within a year ${ }^{[2]}$. However, this species is being genetically introgressed by the hatchery operators or by some other means. As a result, growth rate has been decreased and deformities are common for this species. Cryopreservation technique of this species may be important tools for minimizing this problem. Quality sperm may be transported from the country of origination rather than brood. Cryopreserved sperm can be supplied to different hatcheries for the production of quality seeds which will boost up the aquaculture production in the country. Development of this technique may also minimize the rearing cost of broods in large scale. This may the useful tools to minimize the negative effects of inbreeding and hybridization of this species. 
The aim of the work was to standardize a suitable diluents and cryoprotective agents for cryogenic freezing of Thai sharpunti spermatozoa. In this study, two cryodiluents namely egg-yolk citrate and ureaegg-yolk and 10\% DMSO as cryoprotectants at 1.5 ratios was found very effective for this species.

\section{MATERIALS AND METHODS}

\section{Collection of milt}

The brood fish for the cryopreservation study were collected from the stock of the fish maintained in the experimental ponds. During the breeding seasons those males were mature enough to ejaculate milt were selected for the purpose. Collection of the milt samples was performed by giving gentle pressure through the abdomen. Eppendorfs were held against the tip of the genital papillae. Milt was drawn into the eppendorfs and immediately transferred to the icebox to assure quality. In iced condition the quality of sperm remained unchanged for about 6-7h. The motility of sperm was checked by adding $100 \mu$ of tap water on glass slide and motile sperm was seen in light microscope. Milt with more than $80 \%$ motile sperm was used for the next procedure. Sperm was counted by using hemocytometer to know the number of sperm per ml of milt.

\section{Preparation of diluents}

Twelve sdiluents were used to screen out the suitable ones. The diluents were prepared on the combination of different types of organic and inorganic chemicals. For the convenience of the study, we named diluents$1,2,3,4,5,6,7,8,9,10,11$ and 12. Except diluents-1 and diluents-2, specific name has also been given in parenthesis. The chemical constituents of the Kurokura, $0.9 \% \mathrm{NaCl}$, Fish Ringer, egg-yolk citrate, urea-egg-yolk, Alsever's solution, dilution-1, 2, 8, 12 would be cited in the Fig. 1 and 1-1. Dilution of samples was performed by using diluents and cryoprotectant (both these form cryodiluent) to the milt sample at specified ratios. Dilution of milt was performed by using 12 diluent primarily for Thai sharpunti spermatozoa. The dilution factors were 1:3, 1:4, 1:5 and 1:6. Dilution factor of 1:3 means that 1 unit volume of milt is to be diluted with 3 unit volume of diluent including cryoprotectant. This diluents includes required amount of cryoprotectant fraction. Other ratios of $1.4,1.5$ and 1.6 were prepared in the same way.

\section{Cryoprotectant fraction in diluents}

Cryoprotectant is an integral part in cryodiluent. The part of cryoprotectant is determined in relation to the part of extender rather than that of milt. The parts of DMSO, glycerol and ethanol were $10 \%$ of the extending media. Again, combinations of two cryoprotectants (5\% DMSO $+5 \%$ glycerol) were used for the effectiveness of post-thawed sperm motility. The diluted sperm was equilibrated for 10 $\min$ at $0^{\circ} \mathrm{C}$. The motility of the equilibrated sperm was evaluated and only samples with more than 50\% motility were used for long term freezing.

\section{Freezing}

Computer-controlled freezer (CL3300) and Cryogenesis version 4, for Windows (Cryologic, Pty Ltd., Australia 1998 \& 1999) were used to conduct the freezing trials using the following programme. Two step freezing method was applied for Thai sharpunti spermatozoa i.e. firstly the milt was cooled from $+25^{\circ} \mathrm{C}$ to $-4^{\circ} \mathrm{C}$ at $4^{\circ} \mathrm{C}$ per min, followed by cooling at $10^{\circ} \mathrm{C}$ per min from $-4{ }^{\circ} \mathrm{C}$ to $-80{ }^{\circ} \mathrm{C}$. After reaching $-80^{\circ} \mathrm{C}$, samples were removed from the cryochamber and placed inside labelled tubes attached to the aluminium canes and stored in the numbered canisters within liquid nitrogen dewar ($196{ }^{\circ} \mathrm{C}$ ) for further storage. Straws were retrieved from the LN container dewar using tweezer and thawed in room temperature. The motility of the sperm was assessed under microscope after definite time interval. Eye estimation was used for counting the spermatozoa motility.

\section{Statistical Analyses}

The effects of various diluents and cryoprotectants, the dilution ratios expressed as motile cell percentage were tested by using one way and two ways ANOVA with single and multiple observations. Significant results at $(\mathrm{p}<0.01)$ were further tested using Duncan's Multiple Range Test (DMRT) to identify and rank significant difference between the means.

\section{RESULTS}

Study on the effects of 12 diluents on the motility (\%) of Thai sharpunti (B. gonionotus) spermatozoa in equilibrated period and after 1day

Trials were given with 12 diluents primarily to determine suitable diluents. The diluents were composed of different amounts and combinations of different chemicals which are described in Table1 and Table 2. Cryoprotectant, dimethylsulphoxide (DMSO) was administered at rate of $10 \%$ for the initial trial. Dilution ratios, 1:3 and 1:6 were used for diluents 5, 6, 7, 8 and dilution ratios of 1:3, 1:4, 1:5, and 1:6 were used for rest of the diluents. Corresponding data representing the effects of 12 diluents on equilibrium motility (\%) and post thawed motility $(\%)$ after 1day has been given in the table 3 .

The result showed marked differences in effectiveness of different diluents with $10 \%$ DMSO. The satisfactory percentage of post-thawed motility was recorded in two diluents, egg-yolk-citrate $(>40 \%)$, urea-egg-yolk $(>50 \%)$ which were significantly different $(\mathrm{p}<0.01)$ from each other. Kurokura solution performed moderate results $(>30 \%)$ which was significantly different from the egg- yolk citrate and urea-egg-yolk $(p<0.01)$. The motility of all the milt samples in fresh condition was $80-100 \%$ whereas motility percentage during 
Table1.Chemical composition of different diluents used for sperm preservation of Thai sharpunti ( $B$. gonionotus) spermatozoa. Among the diluents those were composed of more than one chemical have been given in a table. The diluents composed of single chemicals are excluded from the table. For the convenience of the table, serial number of diluents was not maintained

\begin{tabular}{|c|c|c|c|c|c|c|}
\hline Diluents & 1 & 2 & 3 & 10 & 9 & 4 \\
\hline Constituents & $\begin{array}{l}\text { Diluent- } \\
1\end{array}$ & $\begin{array}{l}\text { Diluent } \\
-2\end{array}$ & $\begin{array}{l}\text { Fish } \\
\text { ringer } \\
\text { solution }\end{array}$ & Egg- yolk- citrate & Urea -egg -yolk & $\begin{array}{l}0.9 \% \\
\mathrm{NaCl}\end{array}$ \\
\hline $\begin{array}{l}\text { Sodium } \\
\text { chloride }\end{array}$ & $0.4 \mathrm{~g}$ & $0.6 \mathrm{~g}$ & $231 \mathrm{mM}$ & $0.4 \%$ & $0.3 \%$ & $\begin{array}{l}0.9 \% \\
\mathrm{NaCl}\end{array}$ \\
\hline Urea & - & - & - & - & $0.4 \%$ & $0.9 \mathrm{~g}$ \\
\hline $\begin{array}{l}\text { Sodium } \\
\text { citrate }\end{array}$ & - & - & - & $0.1 \%$ & & $\begin{array}{l}\mathrm{NaCl} \\
\text { dissolved }\end{array}$ \\
\hline $\begin{array}{l}\text { Sodium } \\
\text { bicarbonate }\end{array}$ & $0.1 \mathrm{~g}$ & $0.1 \mathrm{~g}$ & $2.05 \%$ & $\begin{array}{l}\text { Dissolved in } 100 \mathrm{ml} \text { of } \\
\text { distilled water. Streptomycin }\end{array}$ & $\begin{array}{l}\text { Dissolved in } 100 \mathrm{ml} \text { of } \\
\text { distilled water. Streptomycin }\end{array}$ & $\begin{array}{l}\text { in } 100 \mathrm{ml} \\
\text { of water }\end{array}$ \\
\hline $\begin{array}{l}\mathrm{NaH}_{2} \mathrm{PO}_{4} \\
. \mathrm{H}_{2} \mathrm{O}\end{array}$ & $0.041 g$ & $0.041 g$ & - & $\begin{array}{l}(1000 \mathrm{iu} / \mathrm{ml}) \text { and } \\
\text { pancreomycin }(1000 \mathrm{iu} / \mathrm{ml})\end{array}$ & $\begin{array}{l}(1000 \mathrm{iu} / \mathrm{ml}) \text { and } \\
\text { pancreomycin }(1000 \mathrm{iu} / \mathrm{ml})\end{array}$ & \\
\hline $\mathrm{CaCl}_{2} \cdot 2 \mathrm{H}_{2} \mathrm{O}$ & $0.023 g$ & $0.023 g$ & - & were added to the buffer & were added to the buffer & \\
\hline $\begin{array}{l}\text { Calcium } \\
\text { chloride }\end{array}$ & - & - & $2.2 \mathrm{mM}$ & $\begin{array}{l}\text { solution. Egg yolk was added } \\
\text { to the buffer at a ratio of }\end{array}$ & $\begin{array}{l}\text { solution. Egg yolk was added } \\
\text { to the buffer at a ratio of }\end{array}$ & \\
\hline $\begin{array}{l}\text { Potassium } \\
\text { chloride }\end{array}$ & $0.038 g$ & $.038 g$ & $8 \mathrm{mM}$ & $\begin{array}{l}\text { 1:4(egg yolk: buffer). } \\
\text { Therefore } 80 \mathrm{ml} \text { of buffer }\end{array}$ & $\begin{array}{l}\text { 1:4(egg yolk: buffer). } \\
\text { Therefore } 80 \mathrm{ml} \text { of buffer }\end{array}$ & \\
\hline $\begin{array}{l}\mathrm{MgSO}_{4} \\
.7 \mathrm{H}_{2} \mathrm{O}\end{array}$ & $0.023 g$ & $0.023 g$ & - & $\begin{array}{l}\text { was mixed with } 20 \mathrm{ml} \text { of egg- } \\
\text { yolk }\end{array}$ & $\begin{array}{l}\text { was mixed with } 20 \mathrm{ml} \text { of egg- } \\
\text { yolk }\end{array}$ & \\
\hline $\mathbf{M g C l}_{2}$ & - & - & $3.7 \mathrm{mM}$ & & & \\
\hline & $\begin{array}{l}\text { Dissolve } \\
\text { distilled }\end{array}$ & $\begin{array}{l}\text { in } 100 \mathrm{~m} \\
\text { ater }\end{array}$ & & & & \\
\hline
\end{tabular}

equilibrated period in egg-yolk-citrate, urea-egg-yolk and Kurokura solution was $(70 \%),(80 \%)$, and $(60 \%)$ respectively.

Alsever's solution and $\mathrm{NaCl}$ solution gave poor results, $40 \%$ motility in equilibrated period followed by an abrupt decrease (0-30\%) in $24 \mathrm{~h}$. However, the equilibrium motility $(\%)$ varied $(30-80 \%)$ greatly with different diluents. Glucose $(0.3 \mathrm{M}, 0.6 \mathrm{M})$, and fructose solution at $0.6 \mathrm{M}$ levels coagulated the samples during equilibrated period and the postthawed motility was very poor $(0-10 \%)$.

Samples in sucrose solution demonstrated very active cells with high motility percentage $(60 \%)$ but the post-thawed samples did not give any result at all (0$5 \%$ ). Other diluents showed less than $30 \%$ motile cells in equilibrated period with more little percentage of motility in post-thawed condition (0$10 \%)$. From those results it is revealed that, ureaegg-yolk, egg-yolk citrate and kurokura solution gave more than 50\% spermatozoa motility in equilibrated period as well as showed best performance after 24 hours. Glucose and fructose solution were coagulated and $0.6 \mathrm{M}$ glucose showed best cell motility during equilibrated period.
Study on the effects of different concentration of cryoprotectants and dilution ratios (milt: cryodiluent) on the spermatozoal motility of Thai sharpunti spermatozoa for month long observation

Two extenders namely egg-yolk citrate and urea-eggyolk showed best results in terms of spermatozoal motility after 24 hours.

Therefore, further trials were given with different fraction of cryoprotectants and different dilution ratios such as 1:3, 1:4, 1:4, and 1:6 for month long observation after 7 days interval. Corresponding data representing the effects of different dilution ratios with two diluents are given in Table 4. 
Table 3. Effects of different diluents on the motility of Thai sharpunti (B. gonionotus ) spermatozoa both in equilibrated and after 24 hours. Cryoprotectant DMSO was used at $10 \%$

\begin{tabular}{|c|c|c|c|c|c|}
\hline Diluents & $\begin{array}{c}\text { Cryoprotectant } \\
(10 \%)\end{array}$ & $\begin{array}{l}\text { Dilution } \\
\text { ratio }\end{array}$ & $\begin{array}{l}\text { Motility in fresh } \\
\text { condition }(\%)\end{array}$ & $\begin{array}{l}\text { Equilibrium } \\
\text { motility (\%) }\end{array}$ & Motility after 1 Day (\%) \\
\hline \multirow[t]{4}{*}{ Diluent -1 } & DMSO & $1: 3$ & $80-100$ & 30 & $5-10$ \\
\hline & & $1: 4$ & & 30 & $5-10$ \\
\hline & & $1: 5$ & & 30 & $0-5$ \\
\hline & & $1: 6$ & & 30 & $0-5$ \\
\hline \multirow[t]{4}{*}{ Diluent -2 } & DMSO & $1: 3$ & $80-100$ & 20 & 0 \\
\hline & & $1: 4$ & & 30 & $5-10$ \\
\hline & & $1: 5$ & & 30 & $5-10$ \\
\hline & & $1: 6$ & & 20 & $10-20$ \\
\hline \multirow{4}{*}{$\begin{array}{l}\text { Diluent-3 (Fish } \\
\text { Ringer solution) }\end{array}$} & DMSO & $1: 3$ & $80-100$ & 40 & $10-20$ \\
\hline & & $1: 4$ & & 40 & $10-20$ \\
\hline & & $1: 5$ & & 40 & $10-20$ \\
\hline & & $1: 6$ & & 40 & $10-20$ \\
\hline \multirow{4}{*}{$\begin{array}{l}\text { Diluent }-4(0.9 \% \\
\mathrm{NaCl})\end{array}$} & DMSO & $1: 3$ & $80-100$ & 40 & 0 \\
\hline & & $1: 4$ & & 40 & 0 \\
\hline & & $1: 5$ & & 40 & $10-30$ \\
\hline & & $1: 6$ & & 40 & $10-30$ \\
\hline \multirow{2}{*}{$\begin{array}{l}\text { Diluent -5 ( } \\
\text { Glucose- } 0.3 \mathrm{M})\end{array}$} & DMSO & $1: 3$ & $80-100$ & 30 & 0 \\
\hline & & $1: 6$ & & 30 & $0-5$ \\
\hline \multirow{2}{*}{$\begin{array}{l}\text { Diluent }-6 \\
\text { (Sucrose } 0.6 \mathrm{M} \text { ) }\end{array}$} & & $1: 3$ & & 60 & 0 \\
\hline & & $1: 6$ & & 60 & $0-5$ \\
\hline \multirow{2}{*}{$\begin{array}{l}\text { Diluent -7 ( } \\
\text { Fructose } 0.6 \mathrm{M})\end{array}$} & DMSO & $1: 3$ & $80-100$ & 40 & 0 \\
\hline & & $1: 6$ & & 40 & $5-10$ \\
\hline \multirow{2}{*}{$\begin{array}{l}\text { Diluent -8 } \\
\text { (Alsevers } \\
\text { solution) }\end{array}$} & DMSO & $1: 3$ & $80-100$ & 40 & $0-10$ \\
\hline & & $1: 6$ & & 40 & $20-30$ \\
\hline \multirow{4}{*}{$\begin{array}{l}\text { Diluent -9 (Urea- } \\
\text { egg- yolk) }\end{array}$} & & $1: 3$ & $80-100$ & 80 & $40-50$ \\
\hline & DMSO & $1: 4$ & & 80 & $50-60$ \\
\hline & & $1: 5$ & & 80 & $70-80$ \\
\hline & & $1: 6$ & & 80 & $40-50$ \\
\hline \multirow{4}{*}{$\begin{array}{l}\text { Diluent -10 } \\
\text { (Egg- yolk- } \\
\text { citrate) }\end{array}$} & & $1: 3$ & $80-100$ & 70 & $30-40$ \\
\hline & DMSO & $1: 4$ & & 70 & $40-50$ \\
\hline & & $1: 5$ & & 70 & $60-70$ \\
\hline & & $1: 6$ & & 70 & $40-50$ \\
\hline \multirow{5}{*}{$\begin{array}{l}\text { Diluent -11 } \\
\text { (Glucose } 0.6 \mathrm{M})\end{array}$} & DMSO & $1: 3$ & $80-100$ & 60 & $5-10$ \\
\hline & & $1: 6$ & & 70 & $5-10$ \\
\hline & & $1: 3$ & $80-100$ & 70 & $5-10$ \\
\hline & & $1: 6$ & & 70 & $5-10$ \\
\hline & & $1: 3$ & $80-100$ & 60 & $30-40$ \\
\hline \multirow{3}{*}{$\begin{array}{l}\text { Diluent -12 } \\
\text { (Kurokura } \\
\text { solution) }\end{array}$} & DMSO & $1: 4$ & & 60 & $30-40$ \\
\hline & & $1: 5$ & & 60 & $40-50$ \\
\hline & & $1: 6$ & & 60 & $20-30$ \\
\hline
\end{tabular}


Table 2. Chemical composition of different diluents used for sperm preservation of Thai sharpunti ( $B$. gonionotus) spermatozoa. Among the diluents those were composed of more than one chemicals have been given in a table. The diluents composed of single chemicals are excluded from the table. For the convenience of the table, serial number of diluents were not maintained

\begin{tabular}{|lll|}
\hline Diluents & $\mathbf{8}$ & $\mathbf{1 2}$ \\
\hline Constituents & Alsevers & Kurakura solution \\
& solution & \\
$\mathrm{NaCl}$ & $0.4 \%$ & $0.36 \mathrm{~g}$ \\
$\mathrm{CaCl}$ & & $0.022 \mathrm{~g}$ \\
$\mathrm{KCl}$ & - & $1.0 \mathrm{~g}$ \\
$\mathrm{MgCl}_{2}$ & - & $0.008 \mathrm{~g}$ \\
$\mathrm{NaHCO}_{3}$ & - & $0.020 \mathrm{~g}$ \\
Dextrose & - & - \\
$\begin{array}{l}\text { Sodium citrate } \\
\text { Dissolved in } 100 \mathrm{ml} \text { of } \\
\text { distilled water }\end{array}$ & $\begin{array}{l}\text { Dissolved in } \\
100 \mathrm{ml} \text { of } \\
\text { distilled water }\end{array}$ & $\begin{array}{l}\text { Dissolved in } \\
100 \mathrm{ml} \text { of distilled } \\
\text { water }\end{array}$ \\
\hline
\end{tabular}

The results showed that 1:5 ratio at $10 \%$ DMSO showed best spermatozoa motility over other dilution ratios and any concentration of cryoprotectants. In egg-yolk citrate solution, DMSO 10\% with 1:5 ratio gave $70 \%$ motility which was significantly different $(\mathrm{P}<0.01)$ from $10 \%$ glycerol $(40 \%)$ and $10 \%$ ethanol $(30 \%)$. Although, in urea- egg-yolk citrate at1:5 ratio, $10 \%$ ethanol showed $(60 \%)$ motility after one day which decreased to $50 \%$ after one month.In egg yolk citrate solution, $5 \% \mathrm{DMSO}+5 \%$ glycerol at 1:5 ratios suited best $(70 \%)$ at one day than other.

Ten percent glycerol at 1:3 ratios gave poor results $(30 \%)$ in terms of spermatozoa motility in both of the urea-egg-yolk and egg-yolk citrate. After one month $1: 5$ proved its efficacy $(70 \%)$ at $10 \%$ DMSO than any ratios and cryoprotectants both in urea-egg-yolk and egg-yolk citrate. Combined effects of 5\% DMSO+ 5\% Glycerol showed good spermatozoal motility up to the 1 month in urea-egg-yolk solution. The ratio, 1:3 was never proved as a better in any cryoprotectant concentration which was $20-46 \%$.

Among the cryoprotectants fraction (10\%DMSO, $10 \%$ glycerol, $5 \% \mathrm{DMSO}+5 \%$ glycerol and $10 \%$ ethanol) performed in this experiment, 10\% DMSO and combined effects of DMSO+ glycerol proved best results in terms of average spermatozoal motility considering all of the dilution ratios. Glycerol and ethanol showed decreased motility with statistically significant difference $(p<0.01)$ when compared with other cryoprotectants. On the $1^{\text {st }}$ day, in urea-eggyolk diluents with $10 \%$ DMSO on different dilution ratios showed mean motility 59\% which was significantly different from $10 \%$ glycerol (47\%), $10 \%$ ethanol $(45 \%)$. In egg-yolk citrate solution, combined effects of 5\% DMSO+ 5\% glycerol proved its efficacy (mean motile 55\%) than 10\% DMSO (mean motile $52 \%$ ) on $1^{\text {st }}$ day. However, on the $30^{\text {th }}$ day combined effects of DMSO and glycerol failed to show better performance (44\%) than $10 \%$ DMSO $(50 \%)$. Effects of $10 \%$ ethanol and glycerol in both of the diluents were never proved as better cryoprotectants and motile cell percentages were decreased gradually which was also significantly different $(\mathrm{p}<0.01)$. In urea-egg-yolk diluents, on $1^{\text {st }}$ day, average spermatozoal motility was $45 \%$ which became $35 \%$ on $30^{\text {th }}$ day at $10 \%$ ethanol. On the $30^{\text {th }}$ day, $10 \%$ DMSO and 5\% DMSO+5\% glycerol were proved as the best cryoprotectants which showed $53 \%$ and $55 \%$ spermatozoal motility in urea-eggyolk solution respectively.

\section{DISCUSSION}

\section{Effects of diluents and cryoprotectants for the cryopreservation of thai sharpunti spermatozoa}

The choice of extender for cryogenic freezing of gametes first demands knowledge on biology of gametes. The concentration of the components of the spermatozoa should match that of their surrounding media during preservation period, and this surrounding media would be composed of extending and cryoprotecting substances. Sperm morphology and constituents of cyprinids that were available helped to select extenders and cryoprotectants during the present work. The initial choice of diluents was made on the basis of earlier studies preferably, by Kumar ${ }^{[3,4]}$ on Indian major carp and by Linhart and Rodina ${ }^{[5]}$ on common carp. Among the 12 diluents, those composed of with only single composition (diluents- 4, 5, 6, 7, 11) gave poorer results in terms of motility during post-thawed period for the species. It indicates that the osmotic balance of these constituents do not last during long-term preservation.

Egg-yolk citrate solution and the urea-egg-yolk solution were found suitable and could be explained to have specific concentration to balance the osmotic pressure of spermatozoa. The reason behind using egg-yolk citrate and urea-egg-yolk is that, the eggyolk provides a significant protection to the membrane and is called 'membrane stabilizer'. The LDL fraction associated with cell membrane significantly provides protection against injury during cryogenic freezing ${ }^{[6]}$. Again it allows greater and more prolonged survival in the fertilization media ${ }^{[7]}$.

The addition of egg-yolk to the extender was generally beneficial, especially in DMA-and DMSObased extenders. Asparate aminotransferase and lactate dehydrogenase leakage from damaged spermatozoa correlated negatively with the ability of cryopreserved spermatozoa to fertilize eggs. In the present work, the addition of DMSO with both the extenders of egg-yolk and urea-egg-yolk was beneficial in cryopreserving the spermatozoa for a period up to 1 month. 


\begin{tabular}{|c|c|c|c|c|c|c|}
\hline Diluents & Cryoprotectant & Dilution ratio & 1day & 7day & 15day & 1 months \\
\hline \multirow[t]{16}{*}{ Urea-Egg- Yolk } & \multirow[t]{4}{*}{$\operatorname{DMSO}(10 \%)$} & $1: 3$ & 46.66 & 66.00 & 43.33 & 50.00 \\
\hline & & $1: 4$ & 60.00 & 60.00 & 50.00 & 50.00 \\
\hline & & $1: 5$ & 80.00 & 80.00 & 70.00 & 70.00 \\
\hline & & $1: 6$ & 50.00 & 46.66 & 43.33 & 43.33 \\
\hline & \multirow[t]{4}{*}{ Glycerol (10\%) } & $1: 3$ & 30.00 & 30.00 & 30.00 & 30.00 \\
\hline & & $1: 4$ & 40.00 & 40.00 & 36.66 & 36.66 \\
\hline & & $1: 5$ & 60.00 & 60.00 & 53.33 & 50.00 \\
\hline & & $1: 6$ & 60.00 & 60.00 & 60.00 & 60.00 \\
\hline & \multirow{4}{*}{$\begin{array}{l}\text { DMSO + Glycerol } \\
(5 \%+5 \%)\end{array}$} & $1: 3$ & 50.00 & 50.00 & 50.00 & 50.00 \\
\hline & & 1:4 & 60.00 & 60.00 & 60.00 & 60.00 \\
\hline & & $1: 5$ & 70.00 & 70.00 & 60.00 & 60.00 \\
\hline & & $1: 6$ & 60.00 & 60.00 & 50.00 & 50.00 \\
\hline & \multirow[t]{4}{*}{ Ethanol (10\%) } & $1: 3$ & 40.00 & 40.00 & 40.00 & 30.00 \\
\hline & & $1: 4$ & 40.00 & 40.00 & 40.00 & 30.00 \\
\hline & & $1: 5$ & 60.00 & 60.00 & 50.00 & 50.00 \\
\hline & & $1: 6$ & 40.00 & 40.00 & 36.66 & 30.00 \\
\hline \multirow[t]{16}{*}{ Egg-Yolk citrate } & \multirow[t]{4}{*}{ DMSO $(10 \%)$} & $1: 3$ & 40.00 & 40.00 & 40.00 & 40.00 \\
\hline & & $1: 4$ & 50.00 & 50.00 & 50.00 & 40.00 \\
\hline & & $1: 5$ & 70.00 & 70.00 & 66.66 & 60.00 \\
\hline & & $1: 6$ & 50.00 & 40.00 & 36.66 & 60.00 \\
\hline & \multirow[t]{4}{*}{ Glycerol (10\%) } & $1: 3$ & 30.00 & 30.00 & 30.00 & 20.00 \\
\hline & & $1: 4$ & 30.00 & 30.00 & 30.00 & 23.33 \\
\hline & & $1: 5$ & 40.00 & 40.00 & 36.66 & 36.66 \\
\hline & & $1: 6$ & 60.00 & 60.00 & 50.00 & 46.66 \\
\hline & \multirow{4}{*}{$\begin{array}{c}\text { DMSO + Glycerol } \\
(5 \%+5 \%)\end{array}$} & $1: 3$ & 40.00 & 43.33 & 33,33 & 33.33 \\
\hline & & & & & & 4000 \\
\hline & & $1: 5$ & 70.00 & 70.00 & 60.00 & 60.00 \\
\hline & & 1:6 & 60.00 & 60.00 & 50.00 & 46.66 \\
\hline & \multirow[t]{4}{*}{ Ethanol $(10 \%)$} & $1: 3$ & 30.00 & 20.00 & 20.00 & 20.00 \\
\hline & & $1: 4$ & 50.00 & 50.00 & 43.33 & 43.33 \\
\hline & & $1: 5$ & 30.00 & 60.00 & 50.00 & 40.00 \\
\hline & & $1: 6$ & 40.00 & 40.00 & 30.00 & 30.00 \\
\hline
\end{tabular}

Table 4. Effects of two diluents with different fraction of cryoprotectants (DMSO, glycerol , ethanol, DMSO + Glycerol ) at different dilution ratios on the motility of Thai sharpunti ( $B$. gonionotus) spermatozoa for month. Mean values were taken from 3 replicates

Most of the chemical events associated with cryogenic freezing are closely related with the osmotic properties of sperm cell. The cell is made up of water, organelles, dissolved salts, sugars, proteins and lipids, all surrounded by a semi-permeable membrane. This membrane permits selective entrance of extending and cryoprotective media to flow across it and may act as a barrier to the larger molecular solutes. By nature, the low-molecular cryoprotective agent such as dimethylsulphoxide and glycerol tend to move across the cell membrane of spermatozoa and sufficiently maintain an equal concentration of solutes inside and outside the cells. The cryoprotective agent (also called cryophylactic substance) is crucial factor in cryopreservation of spermatozoa since it plays significant role to long-term preservation of sperm.

Kurokura solution was used in common carp, Cyprinus carpio with dimethylsulpoxide as cryoprotectant by Linhart and Rodina ${ }^{[5]}$. Glycerol, as cryoprotectant was not effective as DMSO because it penetrates slowly into the cell membrane ${ }^{[8]}$. In our experiments $10 \%$ DMSO always gave better results in terms of spermatozoa motility both in egg-yolk citrate and urea-egg-yolk solution.

The extending media of glucose $(0.3 \mathrm{M}$ and $0.6 \mathrm{M})$ and fructose $(0.6 \mathrm{M})$ and sucrose $0.6 \mathrm{M}$ solutions coagulated during the equilibration period. The coagulation of milt samples during equilibration period hindered placing those into straws for cryostorage. This criterion resulted the post-thawed motility on spermatozoa less than $10 \%$.

The glucose $(0.6 \mathrm{M})$ and sucrose solution at $0.6 \mathrm{M}$ levels showed high percentage $(60 \%)$ of motile cells with vigorous movement but those did not show any good result in post-thawed period. The vigorous movement could be explained by the stimulating influence for the spermatozoal ATP. When sperm starts to move the flow of ATP to the sperm flagellum lasts only a few minutes ${ }^{[9,10,11]}$.

Cryoprotectants function by reducing the thermal shock. High water solubility and low toxicity to cells are two essential considerations for a chemical to be cryoprotective. In both marine and freshwater fish species, $10 \%$ DMSO has often been used as a protectant for cryopreservation of milt because of its excellent permeation capacity ${ }^{[12,13]}$ and the addition of DMSO makes the medium hypertonic. It is known that sperm motility of several fishes, including Japanese eel, can be initiated in hyper-tonicity ${ }^{[14,15]}$. The use of glycerol or methanol is not well spread. It has been established that the use of cryoprotectants such as glycerol significantly suppresses the sperm motility of all sturgeon species while 10-15\% DMSO acts as the best cryoprotectant ${ }^{[16]}$.

The combined use of DMSO + glycerol in the present work showed considerable effect against cryoinjury over that of glycerol or ethanol. DMSO have more or less similar effect. The concentration of DMSO suited at $10 \%$ of cryodiluent. Besides glycerol at $5 \%$ with $5 \%$ or $10 \%$ of DMSO seemed to have proper influence on revival of spermatozoal motility. However, higher level of glycerol showed poor performance for sperm motility. It might be explained that the higher viscosity of glycerol decreases its permeability to spermatozoal cell and hinder the motility in post-thawed period.

\section{Effects of different dilution ratios (milt: cryodiluent) on spermatozoal motility (\%) of Thai sharpunti}

Determination of the milt: diluents ratio was as another important criterion during the experimental 
period. Four different dilution ratios of 1:3, 1:4, 1:5 and 1:6 were used for the identification of best one which was carried for one month. In general, the 1:5 ratio gave better results over the other three. However, not in all cases this was appropriate, $0.6 \mathrm{M}$ sucrose solution seemed better at ratio of 1:6 to demonstrate motile cells of higher percentage during equilibrated time than at ratio of 1:3 in initial trial.

However extent of dilution may be depends on the concentration of the spermatozoa in gonad. Comparatively less-densed spermatozoal concentration requires lower dilution factor and high densed requires higher dilution factor. The sperm concentration of Thai sharpunti was found $1.2 \times 10^{11}$ cell $/ \mathrm{ml}$ that is more than silver and bighead carp, $2.5 \times 10^{9} \mathrm{cell} / \mathrm{ml}^{[17]}$. From this reason, it needs a higher dilution. The experiment with 1:5 dilution ratio was found more effective than those with $1: 3$ or $1: 4$. The amount of different extender solutions added in milt samples varied in different studies and sperm: extender ratio ranged from $1: 1$ to $1: 9^{[18]}$.

Considerable work has been done on preservation of tilapia (Oreochromis niloticus and Oreochromis aureus) spermatozoa at different dilution ratios with different extenders ${ }^{[19]}$ used fresh water fish saline as an extender with $5 \%$ of each of the cryoprotective agents of DMSO, glycerol and methanol. The ratios used were 1:1, 1:2, 1:3, 1:4, 1:5, 1:10, 1:20 and 1:50. He obtained the best motility at a dilution ratio of $1: 1$ ${ }^{[20]}$ diluted the $O$. niloticus spermatozoa 20 fold with modified fish ringer solution containing $10 \% \mathrm{MeOH}$ and with fish ringer solution ${ }^{[21]}$ containing $5 \%$ $\mathrm{MeOH}$ and $15 \%$ milk powder. Spermatozoa stored up to 6 days prior to cryopreservation were as fertile as freshly frozen spermatozoa and yielded $60.6( \pm$ SE 8.4) developing embryos.

Rana and McAndrew [22] found no significant $(\mathrm{P}>0.05)$ influence on the rates of fertilization of eggs at dilution ratios between 1:2 and 1:20 during cryopreservation of tilapia (Oreochromis spp). Using dilution ratio of $1: 4$, the motility of Indian major carps was investigated by Kumar ${ }^{[4]}$ after cryopreservation period of 0-10 and 10-20 days. In case of Labeo rohita, spermatozoa were found $>60 \%$ $\&>40 \%$ and $>30 \%$ \& $>20 \%$ motile after preservation period of 0-10 and 10-20 days with eggyolk-citrate and urea-egg-yolk solution respectively. In case of Cirrhinus mrigala and Catla catla, the percentages were $>70 \% \&>50 \%$ and $>40 \% \&>20 \%$ with the respective two extenders.

Ultimate success of cryogenic freezing depends on the production of hatchling by using cryopreserved sperm. Two fertilization trials (data not shown) were given but no hatchlings were achieved though massive fertilization was observed during the use of cryopreserved sperm. Sperm cryopreservation is an important technique in aquaculture, and has made significant contribution to long term cryopreservation of sperm for artificial reproduction of many cultured fish species as well as for producing new hybrids in the world. Application of the suitable cryopreservation technology in the farms level may have beneficial effects.

\section{REFERENCES}

1. Kucharczyk D, Kuzawa R, Mamcarz A and Wyszomirska E (1997). Artificial spawning in bream, (Abramis brama L.). Polskie Archiwum Hydrobiologii. 44: 201-205.

2. Siddiqui K and Choudhury SN (1996). MatsyaPukure mach chash manual. National Institute of Local Government (publishers), Agargaon, Dhaka, 606p.

3. Kumar K (1988). A comparative study of various extenders for cryopreservation of carp sepermatozoa. Indian J. Anim. Sci. 58 (11): 13551360.

4. Kumar K (1989). Studies on cryogenic preservation of carp spermatozoa p. 199-206. In Das and Jhingran (eds.) Fish Genetics in India, Today and Tomorrows Printers and Publishers, New Delhi.

5. Linhart O and Rodina M (2000). Cryopreservation of common carp (Cyprinus carpio) and Tench (Tinca tinca) sperm for gene resources conservation. Reprod. Physiol. Fish. 23: 402-404.

6. Babiak I, Glogowski J, Goryczko K, Dobosz S, Kuzminski H, Strezezek J and Demianowicz W. (2000). Effect of extender composition and equilibration time on fertilization ability and enzymatic activity of rainbow trout cryopreserved spermatozoa. Theriogenology 56: 177-192.

7. Billard R (1970). Ultrastructure comparee de spermatozoids de quelques poisons teleosteens. Quaderno 137: 71-79. Baccetti Ed.

8. Ashwood-Smith MJ. (1980). Low temperature preservation of cells, tissues and organs. In Low temperature preservation in medicine and biology. Ashwood-Smith MJ and Farrant J (eds). Pitman Medical, Tunbridge Wells. 19-43. 
9. Gibbons BH, Baccetti B and Gibbons IR (1985). Live and reactivated motility in the flagellum of Anguilla sperm. Cell Motility, 5:333-350.

10. Oda S and Morisawa M (1993). Rises of intracellular $\mathrm{Ca}^{2+}$ and $\mathrm{pH}$ mediate the initiation sperm motility by hyperosmolality in marine teleosts. Cell Motility and the Cytoskeleton, 25:171-178.

11. Ohta H, Kagawa H, Tanaka H, Okuzawa K and Hirose K (1996). Milt production in the Japanese eel, Anguilla japonica, induced by repeated injections of human chorionic gonadotropin. Fish. Sci. 62: 44-49.

12. Stoss J and Holtz W (1983b). Cryopreservation of rainbow trout (Salmo gairdneri) sperm. III. Effect of proteins in the diluent, sperm from different males and interval between sperm collection and freezing. Aquaculture. 31:275-282.

13. Withler FC and Lim LC (1982). Preliminary observations of chilled and deep-frozen storage of grouper (Epinephelus tauvina) sperm. Aquaculture. 27: 389-392.

14. Morisawa M and Suzuki K (1980). Osmolarity and potassium ion: their roles in initiation of sperm motility in teleosts. Science, 40: 11451147.

15. Ohta H and Izawa T (1996). Diluent for cool storage of the Japanese eel (Anguilla japonica) spermatozoa. Aquaculture. 142:107-118.

16. Cherepanov VV, Drokin SI, Ochkur S I, Dzuba BB, Chichachov AS and Kopeika EF (1993).
Freezing of sperm of Azov-Black sea Acipenserids. International symposium of sturgeons. M-K-M, p. 63-64.

17. Khan MGQ (2004). Cryogenic freezing of silver carp (Hypophthalmichthys molitrix) and bighead carp (Aristichthys nobilis) spermatozoa for gene resource conservation. An MS thesis submitted to the Department of Fisheries Biology and Genetics. Bangladesh Agricultural University, Mymensingh. P. 97.

18. Ott AG (1975). Cryopreservation of Pacific salmon and steelhead trout sperm. Ph.D. Thesis. Oregon State Univ., Corvallis, Oreg. 145 p.

19. Chao NH, Chao, WC, Liu KC and Liao IC (1987). The properties of tilapia sperm and its cryopreservation. J. Fish Biol. 30:107-118.

20. Rana KJ, Muiruri RM, McAndrew BJ and Gilmour A (1990). The influence of diluents, equilibration time and pre-freezing storage time on the viability of cryopreserved Oreochromis nitoticus L. spermatozoa. Aquacult. Fish. Manage. 21: 25-30.

21. Ginsburg AS (1963). Sperm-egg association and its relationship to the activation of the egg in salmonid fishes. J. Embryol. Exp. Morphol. $11: 13-33$

22. Rana KJ and McAndrew BJ (1989). The viability of cryopreserved Tilapia spermatozoa. Aquaculture. 76: 335-345. 